\title{
TEACHER LEADERSHIP AND TEACHER PROFESSIONAL LEARNING IN SCHOOLS OF MALDIVES
}

\author{
Ahmed Mohamed", Ahmad Zabidi Abdul Razak, Zuraidah Abdullah \\ Faculty of Education, University of Malaya, Malaysia \\ "Corresponding Author Email: ahmed.mohamed@siswa.um.edu.my
}

\begin{abstract}
Teacher leadership in schools has become a vital area of investigation in supporting teachers' engagement in professional learning. Hence, this survey study aims to examine the influence of teacher leadership on teacher professional learning, using a sample of 371 teachers working in schools of Maldives. Teacher Leadership School Survey (TLSS) and Teacher Professional Learning Scale (TPLS) were used to collect data. The data was analysed using SPSS (Statistical Package for Social Science) version 21.0 with descriptive and inferential statistics. The results of the study indicated that teacher leadership was positively and significantly associated with teacher professional learning based on teachers' perception. The findings also revealed that only two dimensions of teacher leadership - collegiality and developmental focus found as significant predictors of teacher professional learning. Based on the statistical results, implications of the findings were discussed in the context of teacher leadership and teacher professional learning. The areas of significance identified by this study can guide authorities to provide leadership training to foster culture of teacher leadership in schools. Consequently, recommendations and suggestions for future research were also presented.
\end{abstract}

Keywords: teacher leadership, collegiality, teacher professional learning

\section{INTRODUCTION}

Recent years have witnessed developments in the concept of school leadership with re-discovery of substitutes for leadership as leadership focus has moved beyond one central leader (Hendriks \& Scheerens, 2013). Thus, success of schools relies on shared leadership due to complex demands on school leaders (Wilson, 2016), that makes teacher leadership inevitable in schools (Adams, A. Samat, \& Abu Samah, 2018). Teacher leadership has been globally advocated for school improvement and reforms (Aliakbari \& Sadeghi, 2014), and it is an integral part of global educational reform movement (Ali, 2014). Apart from worldwide popularity, teacher leadership has been progressively embedded in the discourse of school change and improvement (Harris, 2010).

The effects of teacher leadership vary at different levels including school, teachers and students (Harris, 2010). Teacher leadership also reflects teacher agency in their effort to improve educational outcomes of the students (York-Barr \& Duke, 2004). However, weak direct relationship was established between teacher leadership and student achievement (Harris, 2010). As widely informed, the benefits of teachers participating in the leadership includes additional support to run the school operations, teachers' perspective taking into considerations for effective decision making, and teachers become more committed to achieve school goals (York-Barr \& Duke, 2004). More importantly, teacher leadership has a positive effect on teachers' classroom practices in terms of effectiveness of teaching and learning (Harris, 2010). 
This indicates that teacher leadership has more direct impact on teachers and their practices.

In fact, teachers with better perceptions and high expectations of teacher leadership roles tend to have higher levels of organisational commitment (Colak, Altinkurt, \& Yilmaz, 2014). Teachers regularly engage in continuous professional development can be recognised as an act of the commitment to learn. Hence, teachers having amplified sense of empowerment and improved professional learning would contribute to better teaching and learning in schools (Wenner \& Campbell, 2017). Teacher leadership capacity and professional growth of teachers would be increased when they engage in leadership roles (Wenner \& Campbell, 2017). Thus, relationship between teacher leadership and teacher professional learning needs to be examined.

The conceptual connection between teacher leadership and teacher professional learning ensues as "professional development is both a cause and an outcome of teacher leadership" (Poekert, 2012). Several studies disclosed that continuous professional development as a strategy to support teacher leadership (Frost, 2012), and teacher professionalism as an important predictor of teacher leadership (Kilinç, Cemaloğlu, \& Savaş, 2015). Despite of these studies on the role professional development on developing teacher leadership, limited research exists on examining the effect of leadership on teacher professional learning engagement. Additionally, lack of empirically based evidence can question the potentiality of teacher leadership in schools (Adams et al., 2018).

Finally, the notion of leadership and professional learning need to be understood within precise details of the cultural and contextual situations (Alexandrou \& Swaffield, 2012). Also, role of teacher leadership has achieved little attention in Maldives, regardless of popularity and extensive literature across the countries worldwide. In Maldives, handful of studies investigated the concept of teacher leadership, relating it to school effectiveness (Ngang, Abdulla, \& Mey, 2010), but not in relation to teacher professional learning. Hence, the current study aims at investigating the influence of teacher leadership on teacher professional learning in the context of Maldives. Accordingly, the study attempts to answer the following objectives:

1. To analyse the level of teacher leadership in schools of Maldives, as perceived by teachers.

2. To analyse the level of teacher professional learning in schools of Maldives, as perceived by teachers.

3. To examine the relationship between teacher leadership and teacher professional learning.

4. To determine which of the teacher leadership dimensions would predict teacher professional learning.

\section{LITERATURE REVIEW}

\section{Teacher Leadership}

Teacher leadership is a form of leadership (Alexandrou \& Swaffield, 2012), and more explicitly a model of school leadership (Bush \& Glover, 2014), which involves ability to influence others to achieve imperative goals of school improvement (Wilson, 2016). 
However, it lacks an operational definition to generalize the field in a broad sense (Newton, Jacobsen, \& Ahn, 2017). The term 'teacher leadership' is rarely defined and conceptualization is extensively varied based on waves of teacher leadership (Wenner \& Campbell, 2017). Hence, informal teacher leaders are utilized along with formal teacher leaders, in this study to conceptualize teacher leadership, as it is established on 'professionalism and collegiality' instead of a titled position (Pounder, 2006). Teacher leadership is "capacity and commitment to contribute beyond one's classroom" (Fullan \& Hargreaves, 1996, p. 13). Teachers' capacity to lead informally has more impact to teacher collaboration compared with principals' leadership and their professional experience (Szczesiul \& Huizenga, 2014). Teacher leadership can be defined as teacher participation in school decision-making and opportunities for teachers to take initiative and lead school improvement (Muijs \& Harris, 2007).

Teacher leadership in the third wave is viewed as a process rather than a position that teachers get leadership opportunities while carrying out teaching duties (Pounder, 2006). Teacher leadership is defined as the "process by which teachers, individually or collectively, influence their colleagues, principals, and other members of school communities to improve teaching and learning practices with the aim of increased student learning and achievement" (York-Barr \& Duke, 2004, pp. 287-288). In this study, teacher leadership is defined as "teachers who lead within and beyond the classroom, identify with and contribute to community of teacher learners and leaders, and influence others toward improved educational practice" (Katzenmeyer \& Moller, 2009 , p. 6). Based on the definition, teachers would practice their leadership to support teacher learning among colleague members in the school community.

\section{Teacher Professional Learning}

Teacher professional learning has been referred as "continuous professional learning" (Adams, 2017). The main affordance of teacher professional learning is linked to teachers sharing their practices openly, and they collaborate and reflect on their instructional practices in acritical manner (Admiraal et al., 2016). Additionally, based on a review of research, Opfer and Pedder (2011) concluded these are "activities that effectively support teachers' professional learning need to be sustained and intensive rather than brief and sporadic". Similarly, Attard Tonna and Shanks (2017) stated that teacher professional learning is situated within school environment of teaching practice where they socially interact. Teacher learning can be connected to their daily work and teachers' need when they are supported with their learning activities (Admiraal et al., 2016).

Teacher professional learning is conceived as continuous and on-the-job learning "activities through which teachers update, extend and deepen their knowledge and skills" (Liu \& Hallinger, 2018, p. 636). To elaborate, it is not randomly selected programs detached from teachers' daily teaching practice work (Killion, 2016). In this study, 'Teacher Professional Learning' is defined as continuous and job-embedded practices or activities taking place with learning orientation, involving both individual and collective learning context that drive teacher learning (Opfer \& Pedder, 2011). Thus, teachers need a learning context, such as teacher leadership culture to enhance their professional learning. 


\section{Teacher Leadership and Teacher Professional Learning}

Teacher leadership leads to professional learning for both individual teacher leaders as well as other colleague teachers (Poekert, 2012). Shared leadership is central component of effective professional learning among teacher groups as it provides an avenue for continuous instructional improvements (Carpenter, 2015). In the context of professional learning communities, teacher leadership promotes teacher professional learning and development using learning tools and facilitation activities such as questioning during discussion of instructional practices, discussion of teaching material samples, analyzing students' results, and providing opportunities for teachers to demonstrate their teaching (Hairon, Goh, \& Chua, 2015).

Teacher leadership has a significant association with both professional development and professional learning communities (Sebastian, Huang, \& Allensworth, 2017). Another study conducted by Law (2011) on leadership roles in facilitating teacher learning identified that more flattened leadership approach by establishment of school capacity for teacher leadership facilitate teacher learning in Chinese context. Beverborg, Sleegers, and van Veen (2015), also conducted a study on teachers in Vocational Education and Training college by using a survey method that demonstrated transformational leadership of team leaders has both direct and indirect effect on teacher learning mediated by team work. However, more empirical research is required on teacher leadership to fill the gaps in knowledge and support teacher leadership demands in various contexts (Adams et al., 2018).

From the perspective of distributed leadership, teachers without any formal leadership position may engaged in leading and managing instructional practices (Spillane, 2015). Teachers engaged in collaborative professional learning requires directions and coordination with the involvement of leaders at different levels including teachers with leadership roles, deputy principal and/or heads of departments, and principal (Kempen \& Steyn, 2017). The growing recognition that principal as a single leader cannot do everything has lead to new leadership frameworks such as teacher leadership approaches and strategies in schools (DeFlaminis, Abdul-Jabbar, \& Yoak, 2016). Schools have organised leadership and structures in different ways (Liljenberg, 2015). This deploys current research to explore the influence of teacher leadership on teacher professional learning in Maldivian context.

\section{Research Framework}

Following the discussion on teacher leadership and teacher professional learning, a research framework is proposed as represented in figure 1. Combination of both theoretical and conceptual framework leads to research framework of the study. Teacher leadership is situated within distributed leadership theory (Harris, 2003; York-Barr \& Duke, 2004). In this study teacher leadership school is viewed from the distributed leadership lens "as a product of the interactions of school leaders, followers and aspects of their situation" (Spillane, Harris, Jones, \& Mertz, 2015, p. 1071). The aspects of the situation can be tools and school routines (Spillane, 2006). Teacher leadership as a shared leadership enhance professional learning as a technique of job-embedded teacher professional development (Poekert, 2012). Teacher professional learning is viewed from the lens of adult learning and situated learning theories (Liu, Hallinger, \& Feng, 2016a). 
Teacher leadership is the independent variable of the study, with seven dimensions of teacher leadership in schools; developmental focus, recognition, autonomy, collegiality, participation, open communication, and positive environment (Katzenmeyer \& Moller, 2001). Teacher professional learning is taken as dependent variable of this study due to the strong influence of professional capacity on classroom instruction (Bryk, Sebring, Allensworth, Luppescu, \& Easton, 2010).

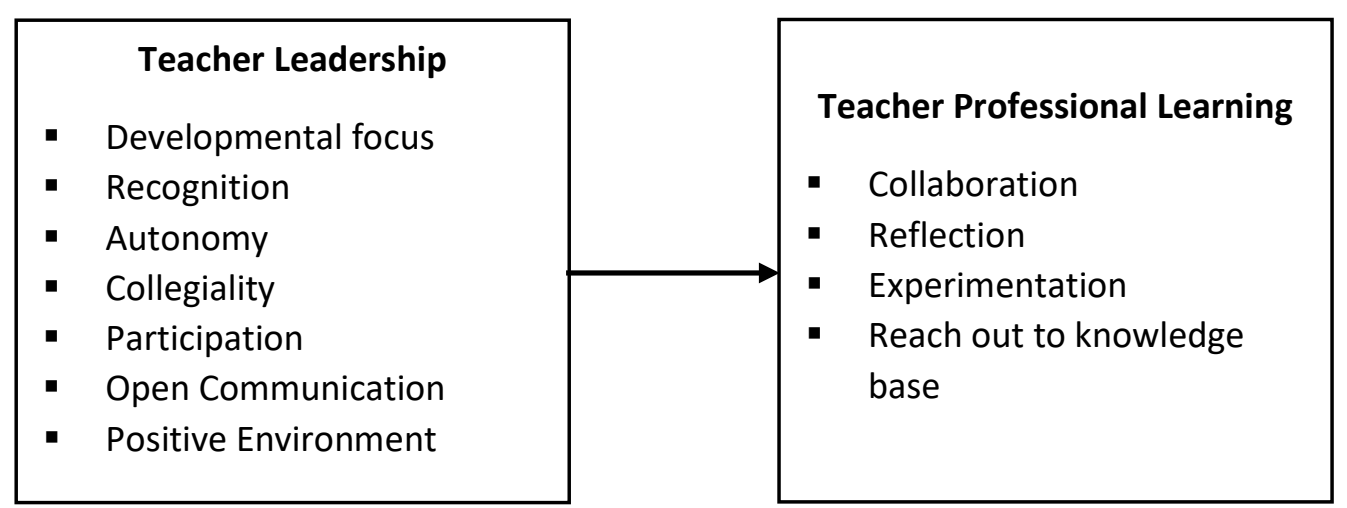

Figure 1. Research Model (Sources: Katzenmeyer \& Moller, 2001; Liu, Hallinger, \& Feng, 2016b).

\section{METHODOLOGY}

\section{Research Design and Participants}

The study employed a non-experimental, cross-sectional research design using survey method to address the research objectives. This research approach is more appropriate to collect large-scale data from as representative a sample population to correlate the variables or predict an outcome on another variable (Cohen, Manion, \& Morrison, 2007). A sample of 371 out of 9242 teachers working in schools of Maldives were selected as respondents of the study. According to Krejcie and Morgan (1970), the sample used in this study is a representative number of the given population. Random sampling techniques was used to select the schools and instrument was sent to all the teachers in the selected schools. Total of 49 schools were involved in the study.

\section{Instrumentation}

The instrument used for the study has two sets of questionnaires. The 'Teacher Leadership School Survey' (TLSS) adapted from Katzenmeyer and Moller (2001) was used to measure the teacher leadership in the schools. The questionnaire with seven subscales was measured on a 5-point Likert Scale, namely: (1) 'Never', (2) 'Rarely', (3) 'Sometimes', (4) 'Often', and (5) 'Always'. In the meantime, teachers' engagement in professional learning was measured using a self-rated 'Teacher Professional Learning Scale' reported by Liu, Hallinger, and Feng (2016b). The items in the scale were drawn from previously developed scales, i.e., (Evers, Kreijns, \& van der Heijden, 2016; in de Wal, den Brok, Hooijer, Martens, \& van den Beemt, 2014; Kwakman, 2003; Schechter \& Qadach, 2012). Total of 27 items with four subscales were measured by using 5points Likert Scale: (1) 'Strongly Disagree', (2) 'Disagree', (3) 'Neutral', (4) 'Agree', and (5) 'Strongly Agree'. 
The instrument was validated by using two international experts and one local expert in the field of leadership and teacher learning. The original TLSS consisted of 49 items. However, one item was fragmented into two items based on experts' feedback due to double barrel. Thus, a total of 50 items were used in this study. The original item was, "At my school I have the freedom to make choices about the use of time and resources". The fragmented items were, "At my school I have the freedom to make choices about the use of time", and "At my school I have the freedom to make choices about the use of resources". Internal consistency of both the sets of questionnaires using measured with Cronbach's alpha. The Cronbach's alpha coefficients were between .65 and .94 for all the subscales of Teacher Leadership School Scale, whereas, Cronbach's alpha coefficients for Teacher Professional Learning subscales were between .81 and .91 . The alpha value of .65 to .95 is satisfactory for Cronbach's alpha reliability of an instrument (Chua, 2013).

\section{Data Collection Procedure}

Approval for carrying out this research was obtained from all the concerned institutions. Next, all the selected schools were communicated through phone conversations. Besides, the researcher visited the selected schools located in Male' City and had face-to-face meeting with the principal to get approval to conduct the study. Furthermore, data collection process was explained. Both hard copies and online questionnaire was administered based on convenience to reach the respondents in different schools across the country. The teachers' consent to take part in the study was sought as an ethical consideration and their participation was voluntary. They were assured that their responses will be kept confidential and anonymous. They were given four weeks to complete the questionnaire. The study was conducted in the first quarter of the academic year 2018 in Maldives.

\section{Data Analysis}

Data gathered for the study were analysed using Statistical Packages for the Social Sciences (SPSS) version 21.0. Both descriptive statistics and inferential statistics were used in the data analysis. Frequency and percentage were used for the demographic information of the respondents. Mean and standard deviation were used to determine the level of teacher leadership and teacher professional learning. Person product-moment correlation analysis was performed to determine the relationship between teacher leadership and teacher professional learning. Multiple Regression analysis was used to determine the percentage of variance in teacher professional learning that can be explained by the teacher leadership. This analysis was used to determine level of predictions as it identifies dimensions of teacher leadership that function as significant predictor of teacher professional learning.

\section{RESULTS}

The findings of the study are presented in this section, beginning with the demographic profile of the participants and followed by explanation to answer the research objectives.

\section{Respondents' Demographic Profile}

The demographic profile of the respondents in Table 1 revealed that $41 \%$ were male teachers and $59 \%$ were female teachers. Among these teachers, $4.582 \%$ teachers were from pre-school, $33.154 \%$ teachers from primary, and $62.264 \%$ teachers from 
secondary / higher secondary. This indicates that majority of the teachers participated in this study teach at secondary or higher secondary level. In addition, $40.2 \%$ of them had completed their Masters/Postgraduate degree, while $31.8 \%$ teachers had Bachelor degree, followed by $22.1 \%$ teachers had diploma, and $5.9 \%$ teachers had certificate level qualification.

Table 1: Demographic Profile of Respondents

\begin{tabular}{lcc}
\hline Demographics & Respondents & Percentage (\%) \\
\hline Gender & 152 & \\
$\quad$ Male & 219 & 51 \\
$\quad$ Female & 22 & 59 \\
Teaching Qualification & 82 & 5.9 \\
$\quad$ Certificate & 118 & 22.1 \\
$\quad$ Diploma & 149 & 31.8 \\
Bachelor's Degree & & 40.2 \\
Masters/Postgraduate & 17 & \\
Level of Teaching & 123 & 4.6 \\
$\quad$ Preschool & 231 & 33.2 \\
$\quad$ Primary & & 62.3 \\
$\quad$ Secondary/ Higher Secondary &
\end{tabular}

\section{Level of Teacher Leadership in Schools}

The first research objective seeks to analyse the level of teacher leadership in schools of Maldives. The level of teacher leadership was measured using 50 items categorised under seven dimensions of teacher leadership, namely; developmental focus, recognition, autonomy, collegiality, participation, open communication, and positive environment. The findings of descriptive analysis for both overall variable of teacher leadership and dimensions of the variable are presented. Teachers' perceived level of teacher leadership practices on the seven dimensions in schools are shown in Table 2.

Table 2: Level of teacher leadership dimensions

\begin{tabular}{lccc}
\hline \multicolumn{1}{c}{ Teacher Leadership Dimensions } & Mean & SD & Level \\
\hline Teacher Leadership (Overall) & $\mathbf{3 . 9 3}$ & $\mathbf{. 5 5 7}$ & High \\
Positive Environment & 4.19 & .769 & High \\
Autonomy & 4.11 & .602 & High \\
Open Communication & 4.04 & .792 & High \\
Collegiality & 4.00 & .695 & High \\
Participation & 3.86 & .781 & High \\
Developmental Focus & 3.70 & .607 & High \\
Recognition & 3.63 & .576 & Moderate \\
\hline
\end{tabular}

Table 2 shows the mean and standard deviation obtained for seven dimensions of teacher leadership in schools. The highest mean score obtained was 4.19 while 3.63 was the lowest mean score among the dimensions. From the seven dimensions of teacher leadership, positive environment displayed the highest mean score ( $M=4.19)$ and the lowest mean score was recognition ( $M=3.63)$. 
As shown in Table 2, overall mean score for the teacher leadership as perceived by teachers was $3.93(\mathrm{SD}=0.557)$. This could be interpreted as the schools in Maldives having high level of teacher leadership. The results indicated that four out of seven dimensions of teacher leadership showed a higher mean than the overall mean score. These four dimensions are; autonomy $(M=4.11, S D=0.602)$, collegiality $(M=4.00, S D=$ $0.695)$, open communication $(M=4.04, S D=0.792)$, and positive environment $(M=$ $4.19, S D=0.769)$. The other three dimensions, namely; developmental focus $(M=3.70$, $S D=0.607)$, recognition $(M=3.63, S D=0.526)$, and participation $(M=3.86, S D=0.781)$ showed a lower mean value than the overall mean of teacher leadership. Regardless of these differences among the dimensions, all the dimensions above 3.63 mean score indicate moderate to high level of teacher leadership in schools of Maldives.

\section{Level of Teacher Professional Learning}

The second research objective seeks to analyse the level of teacher professional learning. The mean and standard deviation obtained for four dimensions of teacher professional learning is shown in the Table 3. From the four dimensions of teacher professional learning, collaboration displayed the highest mean score $(M=4.42)$, and the lowest mean score was reach out to knowledge base $(M=3.42)$. As seen from the Table 3, total mean score for teacher professional learning was 4.12 , as perceived by teachers.

Table 3: Level of teacher professional learning dimensions

\begin{tabular}{lccc}
\hline \multicolumn{1}{c}{$\begin{array}{c}\text { Teacher Professional Learning } \\
\text { Dimensions }\end{array}$} & Mean & SD & Level \\
\hline Teacher Professional Learning (Overall) & $\mathbf{4 . 1 2}$ & .470 & High \\
Collaboration & 4.42 & .551 & High \\
Experimentation & 4.30 & .576 & High \\
Reflection & 4.26 & .521 & High \\
Reach out to knowledge base & 3.42 & .500 & Moderate
\end{tabular}

\section{Teacher Leadership and Teacher Professional Learning}

To examine the relationship between teacher leadership and teacher professional learning, a 2-tailed Pearson correlation coefficient analysis was employed. The analysis reveals significant and positive relationship between teacher leadership and teacher professional learning $(r=.475, p<.01)$, as shown in the table 4 . Based on the results of the study, teacher leadership is moderately related to teacher professional learning $(r=.475, p<.01)$. The 'Rule of Thumb' suggested by Guildford and Fruchter (1973) was used to interpret the strength of the relationship between the variables. According to Guildford and Fruchter (1973), correlation coefficient ( $r$ ) between 0.41 to 0.70 demonstrates a moderate correlation. Hence, the results concluded a positive and a substantial relationship between teacher leadership and teacher professional learning in schools of Maldives. 
Table 4: Pearson Product-Moment Correlation Analysis Between Teacher Leadership and Teacher Professional Learning

\begin{tabular}{lcc}
\hline & Teacher Leadership & $\begin{array}{c}\text { Teacher Professional } \\
\text { Learning }\end{array}$ \\
\hline Teacher Leadership & - & \\
Teacher Professional Learning & $.475^{* *}$ & - \\
\hline
\end{tabular}

** Correlation is significant at the 0.01 level (2-tailed)

* Correlation is significant at the 0.05 level (2-tailed)

\section{Predictors of Teacher Professional Learning}

To determine the significant dimensions of teacher leadership that function as predictors of teacher professional learning among teachers working in schools of Maldives, a multiple regression analysis was used. The results of multiple regression analysis (stepwise) is as shown in the table 5 .

Table 5: Multiple Regression (Stepwise) on Teacher Leadership and Teacher Professional Learning

\begin{tabular}{lcccccc}
\hline & $\mathbf{B}$ & $\boldsymbol{\beta}$ & $\mathbf{t}$ & $\mathbf{S i g}$ & $\mathbf{R}^{\mathbf{2}}$ & Adj R $^{\mathbf{2}}$ \\
\hline Constant & 69.338 & & 17.173 & .000 & & \\
Collegiality & .989 & .379 & 7.396 & .000 & .215 & .213 \\
Developmental Focus & .546 & .183 & 3.570 & .000 & .241 & .237 \\
\hline
\end{tabular}

Note: Dependent Variable: Teacher Professional Learning $F(2,368)=58.479, p<0.05$

Based on the results of multiple regression (stepwise), only two dimensions out of seven dimensions of teacher leadership in schools significantly contributed to teacher professional learning among the teachers. These two dimensions - collegiality and developmental focus - contributed $23.7 \%$ to the teacher professional learning in schools of Maldives.

Individually, collegiality significantly influences teacher professional learning (TPL) with a beta coefficient of $.379(t=7.396, p<0.05)$, while developmental focus significantly influences TPL with a beta coefficient of $.183(t=3.579, p<0.05)$. The dominant predictor of teacher professional learning is collegiality. The t-test results were significant $p<0.05$ with the adjusted $R^{2} .213$. This indicates that the collegiality dimension of teacher leadership contributes $21.3 \%$ of the variance in teacher professional learning. The standardized beta value indicated that when strengthening collegiality dimension increases by one unit of standard deviation, the teacher professional learning will increase by 3.79 unit of standard deviation. From the standard beta value, when strengthening developmental focus dimension increased by one unit of standard deviation, the teacher professional learning also increased by 1.83 units of standard deviation.

As the multiple regression analysis showed that combination of collegiality and developmental focus contributed $23.7 \%$ of variance in teacher professional learning, $76.3 \%$ of the variance in teacher professional learning is unable to be predicted by teacher leadership. Furthermore, it indicates that $76.3 \%$ of the variance might be due to other factors that were not examined in this study. 


\section{DISCUSSION}

The findings of the study showed that teachers have a high perception of teacher leadership culture in their schools. This study found that positive environment was perceived highest level among the dimensions of teacher leadership in schools. Furthermore, developmental focus, recognition, and autonomy indicating lower mean than overall mean of teacher leadership. Evidence from a study conducted in primary schools located in capital city of Maldives, Male' shows relatively similar findings as majority of teachers perceived high level of teacher leadership, positive environment having highest level, and both developmental focus and recognition are lower than overall mean of teacher leadership (Ngang et al., 2010).

The lowest perceived dimension of teacher leadership in this study was recognition. This shows a contradicting finding as developmental focus are perceived as least by the teachers in primary schools in the capital city of Maldives (Ngang et al., 2010). The study results suggest that developmental focus, recognition and autonomy needs much attention to enhance teacher leadership culture in schools of Maldives, regardless of the high perception of teachers.

Results of this study also revealed that teachers have a high perception on their engagement in professional learning. A similar finding showed that teachers in schools of Thailand perceived high level of teacher professional learning (Hallinger, Piyaman, \& Viseshsiri, 2017). In Maldives, teachers collaborate, and experiment more than they reflect on their teaching for the purpose of learning and improving the practices. Furthermore, teachers perceived that they engaged least in reach out to the knowledge base. This indicates that more emphasis should be given on teachers approaching other colleagues or resources to acquire more knowledge.

The findings further revealed that a significant relationship between teacher leadership in schools and teacher professional learning. In addition, a moderate correlation existed between the two variables. The findings are consistent with the study revealing a significant relationship between teacher leadership and two factors of professional capacity; professional development and professional learning community (Sebastian et al., 2017). More importantly, teacher leadership has a moderate relationship with professional development $(r=.57, p<.01)$, and professional learning community $(r=.67, p<0.1$ ) (Sebastian et al., 2017).

Hence, this study suggests that suitable school environment for teacher leadership would enhance teacher professional learning, as teacher leadership is considered as a form of job-embedded professional development (Poekert, 2012). Besides, teachers holding a formal leadership position is not required to perform as a leader (Sinha \& Hanuscin, 2017).

Two out of seven dimensions of teacher leadership are statistically significant predictors of teacher professional learning in schools. The finding of the study implies that teachers' engagement in professional learning will be supported when collegiality and developmental focus in schools are developed. Furthermore, it is observed that collegiality has more intense predictive power and is followed by developmental focus. It is evident that leadership does not solely rely on principals or head of departments, but also other teachers working in the subject departments practice leadership to support colleague teachers (Velarde, 2017). Hence, working with colleagues is the major aspect of teacher leadership to lead within and outside the classroom (Sinha \& Hanuscin, 2017). 
Moreover, this study revealed that five dimensions of teacher leadership, namely; recognition, autonomy, participation, open communication, and positive environment are not significant predictors of teacher professional learning in schools. The research results have shown that collegiality and developmental focus of teacher leadership embedded in school culture are more important antecedents to support teachers' engagement in professional learning.

In comparison with previous studies, this study affirms that teacher leadership has a significant association with teacher professional learning. Furthermore, the influence of teacher leadership on teacher professional learning disclose the fact that teacher leadership as one of the antecedents for professional learning among teachers. This study result contributes to the conceptual connection between teacher leadership and teacher professional learning with empirical evidence.

The findings of this study provide valuable information for policy makers and school principals to initiate and implement teacher leadership in school in order to support school-based teacher professional learning. Culture of teacher leadership needs to be nurtured through practice of shared leadership. Principals should create conditions for collegiality and inculcate developmental focus among teachers of school community. Additionally, it is necessary to provide mentor support and training to school leaders and teacher who are in leadership positions as well as those who are not in the leadership position to develop a culture of teacher leadership.

\section{CONCLUSION}

Teacher leadership has a vital role in schools to support job-embedded professional learning for teachers. The findings of this study revealed a high level of teacher leadership despite three dimensions having lower level than overall mean score of teacher leadership. The significant relationship indicated that increase in teacher leadership increases teachers' engagement in professional leaning. Subsequently, collegiality and developmental focus need much emphasis on supporting teachers' engagement in professional learning, as they are more important predictors of teacher professional learning.

Further studies can be conducted with more exogeneous variables to explain the determinants of teacher professional learning. Additionally, relationship between teacher leadership and teacher professional learning can be investigated with different variables, or teacher leadership as a mediating variable. Additionally, qualitative data are needed to explore the possible reasons for the findings of the study.

\section{REFERENCES}

Adams, D., A. Samat, S. N., \& Abu Samah, H. (2018). Teacher Leadership: Going Beyond Classroom. International Online Journal of Educational Leadership, 2(1), 1-3. doi:10.22452/iojel.vol2no1.1.

Adams, G. (2017). Using a narrative approach to illuminate teacher professional learning in an era of accountability. Teaching and Teacher Education, 67, 161170. doi:10.1016/j.tate.2017.06.007

Admiraal, W., Kruiter, J., Lockhorst, D., Schenke, W., Sligte, H., Smit, B., Tigelaar, D., \& de Wit, W. (2016). Affordances of teacher professional learning in secondary schools. Studies in Continuing Education, 38(3), 281-298. doi:10.1080/0158037X.2015.1114469 
Alexandrou, A., \& Swaffield, S. (2012). Teacher leadership and professional development: perspectives, connections and prospects. Professional Development in Education, 38(2), 159-167. doi:10.1080/19415257.2012.657557

Ali, T. (2014). Development of teacher leadership: A multi-faceted approach to bringing about improvements in rural elementary schools in Pakistan. Professional Development in Education, 40(3), 352-375. doi:10.1080/19415257.2013.828238

Aliakbari, M., \& Sadeghi, A. (2014). Iranian teachers' perceptions of teacher leadership practices in schools. Educational Management Administration and Leadership, 42(4), 576-592. doi:10.1177/1741143213510500

Attard Tonna, M., \& Shanks, R. (2017). The importance of environment for teacher professional learning in Malta and Scotland. European Journal of Teacher Education, 40(1), 91-109. doi:10.1080/02619768.2016.1251899

Beverborg, A. O. G., Sleegers, P. J. C., \& van Veen, K. (2015). Fostering teacher learning in VET colleges: Do leadership and teamwork matter? Teaching and Teacher Education, 48, 22-33. doi:10.1016/j.tate.2015.01.015

Bryk, A. S., Sebring, P. B., Allensworth, E., Luppescu, S., \& Easton, J. Q. (2010). Organizing schools for improvement: Lessons from Chicago. Chicago: The University of Chicago.

Bush, T., \& Glover, D. (2014). School leadership models: what do we know? School Leadership \& Management, 34(5), 553-571. doi:10.1080/13632434.2014.928680

Carpenter, D. (2015). School culture and leadership of professional learning communities. International Journal of Educational Management, 29(5), 682694. doi:10.1108/IJEM-04-2014-0046

Chua, Y. P. (2013). Mastering Research Statistics. Selangor: McGraw-Hill Education (Malaysia) Sdn. Bhd.

Cohen, L., Manion, L., \& Morrison, K. (2007). Research methods in education (6th ed.). New York, NY: Routledge.

Colak, I., Altinkurt, Y., \& Yilmaz, K. (2014). The Relationship between Teachers' Teacher Leadership Roles and Organizational Commitment Levels. Educational Process: International Journal, 3(1-2), 35-51.

DeFlaminis, J. A., Abdul-Jabbar, M., \& Yoak, E. (2016). Distributed Leadership in Schools A Practical Guide for Learning and Improvement. New York: Routledge.

Evers, A. T., Kreijns, K., \& van der Heijden, B. I. J. M. (2016). The design and validation of an instrument to measure teachers' professional development at work. Studies in Continuing Education, 38(2), 162-178. doi:10.1080/0158037X.2015.1055465

Frost, D. (2012). From professional development to system change: Teacher leadership and innovation. Professional Development in Education, 38(2), 205-227. doi:10.1080/19415257.2012.657861

Fullan, M., \& Hargreaves, A. (1996). What's worth fighting for in your school? New York, NY: Teacher College Press.

Guildford, J. P., \& Fruchter, B. (1973). Fundamental Statistics in Psychology and Education (5th ed.). New York, US: McGraw-Hill.

Hairon, S., Goh, J. W. P., \& Chua, C. S. K. (2015). Teacher leadership enactment in professional learning community contexts: towards a better understanding of 
the phenomenon. School Leadership \& Management, 35(2), 163-182. doi:10.1080/13632434.2014.992776

Hallinger, P., Piyaman, P., \& Viseshsiri, P. (2017). Assessing the effects of LearningCentered Leadership on Teacher Professional Learning in Thailand. Teaching and Teacher Education, 67, 464-476. doi:10.1016/j.tate.2017.07.008

Harris, A. (2003). Teacher leadership as distributed leadership: Heresy, fantasy or possibility? School Leadership and Management, 23(3), 313-324. doi:10.1080/1363243032000112801

Harris, A. (2010). Teacher leadership and organizational development. In B. McGaw, P. Peterson, and E. Baker (Eds.), International Encyclopedia of Education (3rd ed., pp. 40-44). Oxford, UK: Elsevier.

Hendriks, M. A., \& Scheerens, J. (2013). School leadership effects revisited: a review of empirical studies guided by indirect-effect models. School Leadership \& Management, 33(4), 373-394. doi:10.1080/13632434.2013.813458

in de Wal, J. J., den Brok, P. J., Hooijer, J. G., Martens, R. L., \& van den Beemt, A. (2014). Teachers' engagement in professional learning: Exploring motivational profiles. Learning and Individual Differences, 36, 27-36. doi:10.1016/j.lindif.2014.08.001

Katzenmeyer, M., \& Moller, G. (2001). Awakening the sleeping giant: Helping teachers develop as leaders (2nd ed.). Thousand Oaks, CA: Corwin Press.

Katzenmeyer, M., \& Moller, G. (2009). Awakening the sleeping giant: Helping teachers develop as leaders (3rd ed.). Thousand Oaks: CA: Corwin Press.

Kempen, M. E., \& Steyn, G. M. (2017). An Investigation of Teachers' Collaborative Learning in a Continuous Professional Development Programme in South African Special Schools. Journal of Asian and African Studies, 52(2), 157-171.

Kılınç, A. Ç., Cemaloğlu, N., \& Savaş, G. (2015). The relationship between teacher leadership, teacher professionalism, and perceived stress. Eurasian Journal of Educational Research, 58, 1-26. doi: 10.14689/ejer.2015.58.5

Killion, J. (2016). How the World's Best Schools Stay on Top: Study's Key Findings Pinpoint Practices That Align with Learning Forward. Journal of Staff Development, 37(1), 62-69.

Krejcie, R. V., \& Morgan, D. W. (1970). Determining sample size for research activities. Educational and Psychological Measurement, 30, 607-610.

Kwakman, K. (2003). Factors affecting teachers' participation in professional learning activities. Teaching and Teacher Education, 19(2), 149-170. doi:10.1016/S0742-051X(02)00101-4

Law, E. H. F. (2011). Exploring the Role of Leadership in Facilitating Teacher Learning in Hong Kong. School Leadership \& Management, 31(4), 393-410.

Liljenberg, M. (2015). Distributing leadership to establish developing and learning school organisations in the Swedish context. Educational Management Administration and Leadership, 43(1), 152-170. doi:10.1177/1741143213513187

Liu, S., \& Hallinger, P. (2018). Teacher development in rural China: how ineffective school leadership fails to make a difference. International Journal of Leadership in Education, 21(6), 633-650. doi:10.1080/13603124.2017.1294266

Liu, S., Hallinger, P., \& Feng, D. (2016a). Learning-centered leadership and teacher learning in China: does trust matter? Journal of Educational Administration, 54(6), 661-682. doi:10.1108/JEA-02-2016-0015 
Liu, S., Hallinger, P., \& Feng, D. (2016b). Supporting the professional learning of teachers in China: Does principal leadership make a difference? Teaching and Teacher Education, 59, 79-91. doi:10.1016/j.tate.2016.05.023

Muijs, D., \& Harris, A. (2007). Teacher leadership in (in)action: Three case studies of contrasting schools. Educational Management Administration and Leadership, 35(1), 111-134. doi:10.1177/1741143207071387

Newton, P., Jacobsen, D. R., \& Ahn, R. (2017). Teacher Leadership: Canadian and American Perspectives. International Journal of Teacher Leadership, 8(1), 1-5.

Ngang, T. K., Abdulla, Z., \& Mey, S. C. (2010). Teacher Leadership and School Effectiveness in the Primary Schools of Maldives. Hacettepe University Journal of Education, 39, 255-270.

Opfer, V. D., \& Pedder, D. (2011). Conceptualizing Teacher Professional Learning. Review of Educational Research, 81(3), 376-407. doi:10.3102/0034654311413609

Poekert, P. E. (2012). Teacher leadership and professional development: Examining links between two concepts central to school improvement. Professional Development in Education, 38(2), 169-188. doi:10.1080/19415257.2012.657824

Pounder, J. S. (2006). Transformational Classroom Leadership: The Fourth Wave of Teacher Leadership? Educational Management Administration \& Leadership, 34(4), 533-545. doi:10.1177/1741143206068216

Schechter, C., \& Qadach, M. (2012). Toward an organizational model of change in elementary schools: The contribution of organizational learning mechanisms. Educational Administration Quarterly, 48(1), 116-153. doi:10.1177/0013161X11419653

Sebastian, J., Huang, H., \& Allensworth, E. (2017). Examining integrated leadership systems in high schools: connecting principal and teacher leadership to organizational processes and student outcomes. School Effectiveness and School Improvement, 28(3), 463-488. doi:10.1080/09243453.2017.1319392

Sinha, S., \& Hanuscin, D. L. (2017). Development of teacher leadership identity: A multiple case study. Teaching and Teacher Education, 63, 356-371. doi:10.1016/j.tate.2017.01.004

Spillane, J. P. (2006). Distributed Leadership. San Francisco, CA: Jossey-Bass.

Spillane, J. P. (2015). Leadership and learning: Conceptualizing relations between school administrative practice and instructional practice. Societies, 5(2), 277294.

Spillane, J. P., Harris, A., Jones, M., \& Mertz, K. (2015). Opportunities and Challenges for taking a Distributed Perspective: Novice School Principals' Emerging Sense of their New Position. British Educational Research Journal, 41(6), 1068-1085. doi:10.1002/berj.3166

Szczesiul, S., \& Huizenga, J. (2014). The burden of leadership: Exploring the principal's role in teacher collaboration. Improving Schools, 17(2), 176-191. doi:10.1177/1365480214534545

Velarde, J. (2017). Instructional Leadership Practices in International Schools in Malaysia: A Case Study. International Online Journal of Educational Leadership, 1(1), 90-117. doi:10.22452//iojel.vol1no1.5

Wenner, J. A., \& Campbell, T. (2017). The Theoretical and Empirical Basis of Teacher Leadership: A Review of the Literature. Review of Educational Research, 87(1), 134-171. doi:10.3102/0034654316653478 
Wilson, A. (2016). From Professional Practice to Practical Leader: Teacher Leadership in Professional Learning Communities. International Journal of Teacher Leadership, 7(2), 45-62.

York-Barr, J., \& Duke, K. (2004). What Do We Know About Teacher Leadership? Findings From Two Decades of Scholarship. Review of Educational Research, 74(3), 255-316. doi:10.3102/00346543074003255. 